\title{
Talking with the Scientists: Promoting Scientific Citizenship at School through Participatory and Deliberative Approach
}

\author{
Federica Cornali \\ Correspondence: Federica Cornali, Department of Cultures, Politics and Society - University of Turin, Turin, Italy. \\ Received: August 24, 2017 \\ doi:10.11114/smc.v5i2.2804 \\ Accepted: November 11, 2017 \\ Online Published: November 20, 2017 \\ URL: https://doi.org/10.11114/smc.v5i2.2804
}

\begin{abstract}
Unceasing and pervasive, techno-scientific innovation has changed the social demand for science education over the last few decades. Science education is no longer asked only to train specialists for the technical and scientific professions or for research, but strives to spread science for the citizen. The challenge is to make most people capable of seeing and understanding the impact of science and technology in everyday life, of thinking critically about them and making informed decisions. In recent decades, moreover, the frequent controversies (e.g. on genetic engineering) - as well as the string of alarming events (such as the climate change) where science and politics failed to provide decisive solutions - have stimulated lively interest in public participation in fields traditionally dominated by specialists expertise. This paper, after a brief introduction to the concept of civic scientific literacy and its recent developments, will focus on practices of deliberative democracy that allow citizens to participate directly in decision-making about socio-scientific issues. Starting from an analysis of an initiative conducted in Italian high schools, the paper discusses the contribution that introducing participatory and deliberative practices in a school setting can play in promoting scientific citizenship.
\end{abstract}

Keywords: science education for citizenship, civic scientific literacy, socio-scientific issues, participatory and deliberative practices, high school, science communication

\section{Introduction}

In recent decades, there has been a growing call for more and better public knowledge of scientific issues. A large number of associations, government agencies and international organizations attach major individual and collective benefits to scientific culture (or scientific literacy, as it is also called), urging governments to take steps to promote it see, for example, UNESCO (1983), National Science Foundation (1983), Science Council of Canada (1984), Royal Society (1985), American Association for the Advancement of Science (2001) and the European Parliament and Council of the European Union (2006).

In particular, the ability to engage in reasoned discourse about science is regarded as a prerequisite to active, informed citizenship. This was emphasized as early as 1985 in an influential report published by the Royal Society. In a vigorous effort to promote the Public Understanding of Science (PUS), the report maintained that scientific literacy is "a major element in promoting national prosperity, in raising the quality of public and private decision-making" (Royal Society, 1985, p. 9). Recently, the European Community acknowledged that "in a knowledge society, democracy requires citizens to have a certain scientific and technical knowledge as part of their basic skills", highlighting the need "to get young boys and girls more interested in science by giving each pupil the basic knowledge they need to act as responsible citizens in the face of scientific choices" (European Commission, 2002, p. 11).

The sheer number of such statements testifies to the unanimously recognized need for more civic scientific literacy (CSL), viz., the level of understanding necessary to follow and make sense of public-policy issues involving science or technology (Miller, 2010). However, what exactly constitutes CSL and how it can be achieved are still far from settled. According to Miller and Pardo (2005), CSL must necessarily include two basic dimensions: a basic vocabulary of scientific terms and concepts, and an understanding of the process and methods of science. Though one may agree with this view, these skills would seem necessary but not in themselves sufficient to enable a lay person to understand and deal with the challenges of a highly technological globalized society. They should be accompanied by the ability to understand, evaluate and criticize the applications and social impact of new scientific ideas. To achieve full CSL, the individual should also be able to develop skills that are more specifically social in nature, such as the ability to 
participate in public debate and contribute to collective decisions. Not only: the public must be motivated to participate, or rather to have confidence in their abilities and to know how and where they can make themselves heard. The notion of CSL thus deserves further investigation, not only as regards how its constituent dimensions can be identified and defined, but also as regards the settings and ways that contribute to its formation.

This paper, after a brief introduction to the notion of CSL and its recent developments, will give particular attention to the role of the school in instilling the scientific competence needed for full participation in social life. In particular, the paper will present and discuss Scienza Attiva, a project that takes place in Italian upper secondary schools. This project draws on the principles of participatory and deliberative approach in order to raise young people's awareness of socio-scientific issues, encouraging them to participate to public debate and exercise scientific citizenship.

\section{A Paradigm Shift}

CSL is widely recognized as an important principle and goal for our contemporary societies. The current social demand for science education, in fact, does not center only on training specialists for the technical and scientific professions or for research, but strives to spread a package of skills and competencies that will enable the majority of individuals to read about scientific matters, understand them, and express an informed opinion. In recognition of this need, a growing number of science communication activities have been addressed to the general public over the years. This set of initiatives includes science-themed festivals, open house days organized by research institutes, public lectures and educational activities for children. Nevertheless, the route that leads to what has been called "citizen science" still remains to be mapped. The obstacles that stand in the way of CSL are numerous, and arise in different social spheres. Schools and educational institutions are involved, as are the media system and the world of science. And paradoxical though it may seem, one of the things that has hindered the development of CSL has been the particular conception of "scientific literacy" and "science communication" long adopted by the experts. A brief overview of the last few decades of research on the subject will allow us to explore this aspect further.

As early as 1975, Shen saw CSL as an essential component of scientific literacy. In Shen's view, scientific literacy consists of three components: $i$.) "Practical scientific literacy", or scientific knowledge that can be applied to help solve practical problems; ii.) "Civic scientific literacy", which provides people with a level of understanding of scientific terms and constructs sufficient to read a daily newspaper or magazine and to understand the essence of competing arguments on a given dispute or controversy; iii.) "Cultural scientific literacy", an appreciation of science as a major human achievement. Later, many other authors drew attention to the need for citizens to have the scientific skills necessary to make informed decisions and participate in decisions that affect their own lives and the environment - see, for example Arnos (1983) and Miller (1983). This new awareness, promoted by the Royal Society's seminal 1985 publication, "The Public Understanding of Science", was at odds with a conception of scientific dissemination that left no room for public involvement. Science communication was long considered to be a unilateral, top-down process of transferring incontrovertible knowledge from a small group of scientists or experts to a wide audience marked by spotty knowledge, misconceptions, irrational beliefs, and cultural and/or religious prejudices. This paternalistic approach, though calling for increasing efforts to be made in science education at all stages of the life cycle, in fact considered lay people unfit for participating in science policy decisions (Shamos, 1995). The view of the public perpetuated by this approach - which Hilgartner (1990) has aptly termed the "deficit model" - implicitly affirms that "most people do not make enough effort to find out and engage in some form of self-directed literacy necessitated by their existence in a society where the products of techno-science are pervasive. It is built on [...] an implicit explanation of scientific illiteracy as self-exclusion or apathy towards the existing science learning opportunities" (Tlili \& Dawson, 2010, p. 445).

In the opinion of Jon D. Miller - apparent from many of his writings, and effectively summarized by Bauer, Allum \& Miller (2007) - people can be said to be scientifically literate individuals if they show: a) a knowledge of basic textbook "facts" of science; b) an understanding of scientific "methods" such as probability reasoning and experimental design; c) an appreciation of the "positive outcomes" of science and technology for science; d) the "rejection of superstitious beliefs". Miller thus maintains that having negative or critical attitudes towards science or, for example, believing in astrology or in the existence of UFOs disqualifies a person from being scientifically literate. These definitional criteria seem overly restrictive, and lead to paradoxical results. Indeed, by these lights even several illustrious scientists of the past would be scientifically illiterate: is well known that Isaac Newton was a student of alchemy, Johannes von Kepler drew up horoscopes, the naturalist Alfred Russell Wallace believed in spiritualism, and the famous chemist and physicist William Crookes was convinced of the existence of ghosts. The criteria set out by Miller also seem to flout the very presuppositions of science: they ignore the factual data (that beliefs and scientific knowledge coexist cannot be denied) and seem vaguely intolerant.

This kind of approach endorses a description of science as a pure, absolute entity, totally detached from cultural and historical variables. Since the Nineties, however, numerous studies have drawn attention to the local, situated character 
of science and its technological applications. Science is not merely an individual activity, but a collective practice, in which competing ethics face off in concrete processes, and in specific contexts, consisting of heterogeneous actors linked by complex social relationships and interests (Bowker \& Star, 1999; Mackenzie, 1996). According to this new orientation, the lay public cannot be considered only as the recipient of information and education, but is itself a repository of forms of knowledge and understanding arising from situations and specific contexts. The "deficit" to be guarded against is thus no longer that of the public, but that of academic science, scientists and experts. The latter are considered as harboring prejudices that make them unable to communicate and build relationships based on trust and participation with the general public (Bauer et al., 2007).

It is clear that the move from the Public Understanding of Science (PUS) model to a more inclusive Public Engagement with Science and Technology (PEST) does not stem only from debate among science communication scholars. On the one hand, in fact, it incorporates different notions of citizenship; on the other, it reflects growing tensions in the relationship between science and society. In recent decades, we have witnessed the gradual erosion of the paternalistic concept of the state as a benevolent entity capable of protecting individual and collective interests. Government authorities and the economic and intellectual elites (together with scientists or experts in various fields) have long been credited with the ability to make key decisions in the name and on behalf of the public, to protect them from the risks related to health and the environment. Now, however, citizens have shown themselves increasing able to form their own opinions on controversial socio-scientific issues, and thus feel entitled to make decisions that directly affect their lives and public goods.

This need is doubtless part of the broader crisis of the liberal model of representative democracy. But the ambivalent relationship between citizens and the world of science and scientists is also a factor. Over the past decades, the widespread conviction that science and its technological applications can bring unlimited advances in human potential and a better quality of life has been replaced by doubts and uncertainties. Although citizens still trust and hope in science's ability to address major challenges - such as the treatment of disease, the energy supply - they no longer seem willing to overlook the potential risks (radioactive, chemical and biological) that its technological applications can (or could) entail.

Public confidence has been repeatedly shaken by a series of events (such as the bovine spongiform encephalopathy epidemic or the Fukushima nuclear disaster) where science failed to give timely warning or provide decisive solutions. Frequently, citizens are also faced with controversy within the scientific community itself: on issues such as genetically modified foods or global warming, qualified scientific experts have produced conflicting evidence or proposed different interpretations of the same results (Bingle \& Gaskell, 1994). Thus, we have passed from complaints of the "public's skills deficit", to recriminations about "scientists' communication deficit". What is clearest now, however, is the "deficit of public trust in science and science policy" (Tlili \& Dawson, 2010).

\section{Exercises in Participation}

The crisis of legitimacy and trust that has recently swept through scientific institutions and policies has called the mechanisms of delegation typical of representative democracy into question, shifting the emphasis to practices that permit citizens to participate directly in decision-making.

Over the past decades, several well-known episodes - repeatedly mentioned in the literature on the subject - have highlighted the importance of lay expertise in policy decisions regarding health and the environment. The most famous of these is probably the case of radioactive fallout in the English region of Cumbria, following the accident at the Chernobyl nuclear reactor in 1986. The sheep farmers of the area proved to know more about local soil composition and grazing habits than the experts sent by the government to gauge the level of cesium contamination and decide whether to restrict the meat trade (Wynne, 1996). Following such episodes, there has been a growing interest in practices inspired by the theories of deliberative democracy (Habermas, 1997; Rawls, 1993; Dryzek, 2000) that provide citizens with opportunities to make proposals that can be considered by the institutions (Wilsdon \& Willis, 2004).

For socio-scientific issues in particular, a number of deliberative practices have been tried, including "round tables", "citizens" conferences", "planning cells", "future search conferences", "citizens' juries", "voting conferences" and "scenario workshops". But the citizen participation model which is most widely cited and has inspired the largest number of initiatives is the so-called "Danish consensus conference model". This practice was instituted in the 1980's by the Danish Board of Technology, which created a panel of citizens tasked with making recommendations to the nation's Parliament. Gaining favor, the "consensus conference" model was soon applied to discuss a wide range of issues around the world: genetically modified foods in France (1998), the future of transportation in Israel (2000), cloning in South Korea (1999), genetic testing (2001) in Germany. This model involves dialog - usually open to anyone who wishes to take part - between citizens, experts, and representatives of the media and the political world, on a controversial scientific or technological topic. A group of citizens (the "citizen panel" or "lay panel") are introduced to 
the topic under discussion and provided with basic information. They then formulate questions to a group of scientists or technicians (the "expert panel") and discuss the most controversial aspects with them. At the end of the discussion, the citizens' group produces a final document, presenting its conclusions and recommendations. The final document is thus an expression of the extent to which the panel can reach consensus. Supervision by an "advisory" or "planning committee" ensures that the all the rules of a democratic, fair and transparent process are followed. A facilitator is present throughout the process to put people at their ease and encourage them to work together, focusing attention on key questions and moderating the debate (Andersen \& Jæger, 1999). The "consensus conference" is thus a transparent and documented process, which takes place according to pre-established steps, and in which experts and the lay panel have clearly defined roles in relation to each other.

Though public deliberation processes are very popular since they emphasize dialog and participation, they can be problematic in terms of appropriateness and effectiveness. As can be seen from the literature, four issues are particularly critical.

First, the knowledge and skills required for a successful public debate are usually very complex and not readily come by. Often the available information is incomplete and the sources are in conflict with each other. Not only, but as Bingle \& Gaskell (1994) have pointed out, techno-scientific disputes are often based on assertions and not on facts. It is thus difficult for the lay person to determine which information is relevant and can be relied on in the decision-making process.

Second, it is clear that the "public interests" defended by deliberative democracy initiatives are abstract entities (Burgess, 2014). Frequently, the people participating in PEST events are drawn from particular categories who are directly involved in the issue under discussion. For example, they may be residents of a particular area, people in a given profession, or members of special interest groups. Past experience has shown that the lay panel thus often consists of individuals who are already very aware of the problem. However, panel membership is not only the result of self-nomination by certain interested individuals, but also of the self-exclusion of others. The latter are often less educated individuals or belong to minority groups. Consequently, assuming that participants in deliberative processes are in any way representative of the general population is, to say the least, naïve. Nor must we forget that many disputes have very broad boundaries for representation. As Jasanoff (2004) appropriately asks: should citizens who are called upon to express views on issues such as global warming or acid rain be selected on a regional, national or global basis?

The third critical element is highlighted by the observations of numerous authors, who point out that even in initiatives that purport to promote public engagement with science, there is no lack of technocratic arrogance on the part of scientific and political elites. Goven (2003) has explored the use of the consensus conference in New Zealand, and he argued that the participants attempting to problematize the socio-technical issues were constrained by the "dominant frame of scientific and economic rationality" (p. 437). Earlier, Dunkerley \& Glasner (1998) and Irwin (2001) also noted particular problems with the dominance of technocratic frames.

Finally, the fourth critical element regards the intrinsic futility of attempting to involve fictitiously (or symbolically) the public in scientific issues through dialog or any other means (Wynne, 2006). It is widely held that the consensus conference, like other practices of deliberative democracy, is in fact little more than an attempt to artificially restore trust between citizens, scientists and public institutions, but with few practical consequences. Horlick-Jones et al. (2007), following a systematic analysis of many such experiences, conclude that it is often not at all clear how politicians will use the results of the dialog process and, above all, it is not clear how much weight they will have in policy decisions. There is thus a risk that the practices of deliberative democracy will become exciting but largely inconclusive exercises, in which citizens' actual involvement is marginal and institutional actors forgo none of their decision-making prerogatives.

Assigning simple labels to the four points made above, I can summarize by saying that "inadequate knowledge", "selective representation", "techno-scientific dominance" and "substantial inconclusiveness" are the main shortcomings of these attempts to put deliberative democracy into practice. But this is not to suggest that the imperfections and weaknesses in public participation initiatives for decisions about scientific policy are reason to abandon them. Rather, citizens' growing demand for scientific information and participation in decision-making suggests that more effort should be made to improve and disseminate them.

\section{The Role of the School}

The acknowledged importance of science education in creating active, informed citizenship is explicitly expressed since decades in the guidelines for school programs. At the end of the Eighties, the UK's National Curriculum Council declared that: "Appreciating the contribution science makes to society will encourage pupils to develop a sense of their responsibilities as members of society and of the contributions they can make to it" (National Curriculum Council, 1989, p. 5). Even organizations such as the American Association for the Advancement of Science (1989) and the National 
Research Council (1996) in their education proposals recognized the crucial role of schooling in preparing students for decision-making on socio-scientific issues. The link between scientific competence and the exercise of citizenship is now so widely accepted that the two concepts are inextricably combined in the definition of scientific literacy proposed by the PISA (Programme for International Student Assessment) survey of student skills: "Scientific literacy is the ability to engage with science-related issues [...] as a reflective citizen" (OECD, 2013, p. 7).

CSL quickly became an important educational goal. It does not seem too much to say that science teaching is a vehicle for implicit values that can help form active citizenship. The purpose of science education is not only to provide the concepts, theories and terms for understanding scientific issues. It also serves to contribute to developing a special "way of knowing" centering on observation, analyzing the influences of factors, looking for empirical evidence and generative mechanisms, and systematic doubt. These lessons can contribute to forming future citizens who are aware, involved and critically-minded.

Schools, institutionally charged with the responsibility for science education and building CSL, have not always risen to this challenge. Often, the approach that prevails in the classroom is that of deductive teaching, based entirely on presenting concepts and theories through examples, illustrations and exercises. This is not surprising: in formal education settings, the method - based on systematic, sequential transmission of theoretical knowledge, patterns of thinking and technical skills - still predominates. The "deficit model" is not only the basis for most teaching, but also for much of the teacher-student relationship and the school organization itself. It seems that the failure to stimulate classroom discussion can be attributed in particular to the science curriculum. And teachers, in turn, do not encourage skepticism. Kolst $\varnothing$ observes that in Norway - but the same could be said of other countries - "science teaching in schools traditionally has been, and still is, authoritarian", and he adds, "what should the students be critical about? The law of ideal gases? The conservation of energy?" (Kolstø, 2000, p. 648). By contrast, Sadler (2010, p. 761) states, and I fully agree with him, that "science curriculum offers ample opportunities for engaging students in discussion of controversial issues". What is important is to know how to seize them. With the changing social demand for science education, notional and decontextualized teaching is no longer adequate. Teaching divorced from contemporary social issues can "help students to participate intelligently in making political decisions involving science and technology?" (AAAS, 1989, p. xix-xx). Science and technology are pervasive in contemporary society, requiring science education not only to prepare individuals for technical professions or research, but also to build active citizenship. To empower students as citizens, there is a need to emphasize science as a social practice which is closely linked to its economic and cultural context, thus recognizing the human character of science, its values and its limits.

One of the major forces behind the call for regenerating science education programs was a new academic field developed between the Seventies and Eighties, called Science-Technology-Society, or STS. It is an interdisciplinary and holistic domain whose central focus is "the analysis and explication of science and technology as complex "social constructs" entailing cultural, political, economic, and general theoretical questions' (Cutcliffe, 1996, p. 291). STS suggests that science teaching should not only consider the traditional disciplines, but should also draw on the stimuli arising from everyday life (sports, diet, communication, security). Studying science in its social and cultural context makes it possible to take students' needs, expectations and stock of knowledge into account, encouraging them to examine and discuss techno-scientific issues - from urban pollution to genetic modification, and from the production of nuclear energy to the use of stem cells - and thus learn science by dealing with problems.

STS requires a complete rethinking of traditional teaching, but the benefits of adopting this perspective seem undeniable. They consist mainly in the greater interest shown by the students towards science (Bennett et al., 2007), better results in terms of learning and understanding scientific topics (Lubben et al., 2005; Bennett et al., 2007), and the maturation of critical thinking and social responsibility (Gilbert, 2006; Ryder, 2002). Ultimately, the purpose of STS programs is to help students make sense out of their everyday experiences by integrating their personal understandings of the natural, social, cultural and technological environments around them (Aikenhead, 2002).

However, it should be noted that, despite the widespread appreciation that has greeted the STS, it has never been taken as the main paradigm for science teaching. Indeed, in the opinion of Gaskell (2001), Aikenhead (2003) and Turner (2008), it has never actually become part of usual school practice. Thus, the STS approach has generally not gone beyond rhetoric: its principles are touted in schools' syllabi or teaching programs, but seldom implemented. In fact, a certain numbers of headmasters and teachers have opposed the paradigm shift to STS. Some, in all probability, so as not to have to adapt to a new, more dynamic and more complex, way of teaching. Others may not have felt adequately trained and supported. And some have expressed concern that the STS programs do not prepare students for "real science". This alarm was shared by Shamos, who feared that schools, "dominated by the social science community" (Shamos, 1995, p. 67), could become a vehicle for anti-science and Luddism. From this standpoint, teachers' unwillingness and their partiality for the traditional curriculum stem mainly from how they have been socialized into education: loyalty to their own academic community, and its myths, is reflected by a preference for an abstract and 
decontextualized science (Davis, 2003). However, more frequently, teachers do not have the possibility to set up STS programs due to specific school conditions that restrict their field of action.

Even among the most ardent supporters of the STS strand, there are those who warn against the risk that attention could focus on domains that are completely different from those of science, such as law, economics, religion and politics. These arguments point to another fear, particularly widespread in certain intellectual and institutional circles: that the spread of the STS approach might encourage excessive political activism among students and strident social criticism.

Nevertheless, recent decades have seen several educational programs inspired by approaches which emphasize putting science in context and promoting links between science, technology and society. They have entailed a real renegotiation of the culture of science teaching, proposing new content as well as new classroom materials. Among the most significant experiences we remember, for example, the initiatives promoted by the socio-scientific issues movement that offers a way to explore the nature of science and the relationship between science and society dealing with contemporary socio-scientific controversies (Driver et al., 2000; Kolstø, 2001; Sadler et al., 2004; Albe, 2008).

In line with these approaches there is Scienza Attiva, a project that attempts to achieve the same goals using the practices of deliberative democracy, such as the consensus conferences discussed above. Scienza Attiva has been carried out in Italian secondary schools for over seven years and draws on the principles of participatory democracy to prepare future citizens by building civic scientific literacy.

\section{A Case Study}

Scienza Attiva is a national project designed and conducted by Agorà Scienza, an Inter-University Center whose partners include all the universities in Piedmont (Italy). Its subtitle, "Young People and Participatory Science", draws attention to its goal of engaging students in the discussion of current scientific topics of significant social relevance. Drawing its inspiration from the "consensus conference" model, Scienza Attiva consists of a dialog between students and experts and a deliberative process regarding selected socio-scientific issues.

The project, which lasts for almost the entire school year (roughly from November to April) consists of four phases, respectively called "Prior knowledge", "Information", "Dialog" and "Final proposals". These steps take place in succession according to a clearly defined schedule with specified start and end dates.

- In the first stage, students speak freely, expressing the knowledge they already have about the topic under discussion. Prior knowledge, once activated and enhanced, is the starting point for producing further and more extensive knowledge. In the Scienza Attiva project, this knowledge is mobilized by choosing themes from current events or issues close to the students' own experience (for example, air pollution or energy production and consumption).

- The second stage fulfills a training/information purpose: students learn the topic being discussed by viewing ad hoc material prepared by scientists (in different levels of detail and therefore different levels of difficulty), or from other sources of their choice.

- The third phase is based on dialog: students and scientists interact without filters or mediation through an exchange of questions and answers.

- The fourth stage is the final one; on the basis of lessons learned from the documents, critical reflection and exchange of dialog, the classes - in an exercise in deliberative democracy - prepare scenarios and/or make suggestions. During a final live event open to all classes participating in the project, a synthesis of all the proposals is achieved, and a concluding document is submitted to the participating scientists and institutions.

Scienza Attiva shows unquestionable affinities with the "consensus conferences". There are clear correspondences in the fundamental principles: the focus on a specific topic, the debate between experts and the lay panel, the process's division into distinct, predetermined steps, its public dimension and documented traceability, and the final deliberation. There are also a number of similarities from the purely practical standpoint. The Agorà Scienza Interuniversity Center fulfills the role of "project management": the team manages and organizes the project and this includes financing the project, choosing the topics for discussion, recruiting the lay panel, providing practical assistance, maintaining the website, finding venues for live events, and ensuring that the final document is disseminated. The teachers act as "facilitators": their task is to ensure that their classes engage in fruitful debate in which all opinions can be freely expressed without being quashed by those students who tend to dominate. To prepare teachers for their role as facilitators - an unusual one for them - a training meeting (which is also available on streaming video) with a professional facilitator takes place at the beginning of the project. During this meeting, the method and purpose of the deliberative practices are illustrated, and simulations are carried out. This professional facilitator is a full member of the panel of experts involved in Scienza Attiva, and thus advises teachers who request assistance for the entire duration of the project. 
This undeniably ambitious project could be conducted on a large (national) scale thanks to a combination of two spaces. The first is a physical space composed by the school facilities - classrooms, laboratories, computer rooms - where students and teachers examine documents, discuss and draw up scenarios about the proposed themes. The second is a virtual space, afforded by the website www.scienzattiva.eu.

In addition to being a storehouse and archive of educational materials illustrating the topics covered by the project, the Scienza Attiva website is a true workspace. It provides sharing tools that use the type of interaction typical of social networks to facilitate the exchange of information. The site includes "class notice board" and "public notice board" web pages where students can post documents respectively for internal use or targeted to the whole Scienza Attiva community, as well as special sections with videos in which scientists present their work and answer the questions put to them.

\subsection{Method and Results}

The complexity of Scienza Attiva makes evaluating its results particularly difficult. In fact, the project involves a plurality of actors (students, teachers, scientists), includes a range of different activities, and uses both live and virtual methods. It has also grown significantly over the years: what started as a regional program involving a hundred-odd students is now nationwide in scope, with several thousand participants. This change led to a rethinking of how to assess the project's achievements, starting a pilot evaluation process which is still under way. In the first years, Scienza Attiva was evaluated by administering two questionnaires to students attending the final live event: one before the event and one at the end of the event. The main purpose was to detect any changes of opinion about each socio-scientific issue debated during the project. Pre and post-event questionnaires asked participants to indicate the extent to which they agreed with the main points raised, choosing from the following options: "Not at all", "A little", "Quite a bit", "Very much", "Don't know". Changing from "Not at all" to "A little" and from "Quite a bit" to "Very much" was interpreted as a change in intensity, i.e., the respondent's opinion per se has not changed, but has weakened or been given more emphasis. Shifting from "Not at all" to "Quite a bit", by contrast, is a change of opinion, and these cases were thus labeled as "change of position" (from agreement to disagreement or vice versa). Lastly, going from "Don't know" to any other response option was considered as a move from uncertainty to certainty, and in the opposite case, from certainty to uncertainty. The answers provided by students to the pre- and post-event questionnaires showed that opinions changed significantly after face-to-face discussion of certain issues. For example, the first time the project was held - in the 2008-2009 academic year, with 119 students participating - it was observed that 39\% of the students had a "change of position" after the debate about "the civil use of nuclear energy", while $4 \%$ had a "change of intensity", $9 \%$ went from certainty to uncertainty, $4 \%$ from uncertainty to certainty, and $43 \%$ did not change opinion. After the debate about "expanding restricted traffic areas to solve the problem of air pollution", $32 \%$ of the students had a "change of position", 27\% a "change in intensity", and 41\% did not change opinion (Agnella et al., 2015). Obviously, Scienza Attiva's purpose is not to manipulate individual preferences, but to raise awareness about socio-scientific issues, stimulating dialog and democratic debate. From this point of view, the change in opinions - or the change in their intensity - testifies to the effectiveness of the deliberative process: after students were informed and participated in the discussion, their opinions are different from those they expressed earlier (Fishkin, 2009).

Over the years, the growing number of students, teachers and scientists participating in Scienza Attiva and the project's nationwide spread has increased the importance of the project's online platform. It thus became necessary to ensure that the project was not assessed only on the basis of the final live event, as the small proportion of students taking part could no longer be considered as representative. An even more urgent need, given the Scienza Attiva project's aims and methods, was to introduce a form of "participatory evaluation", or in other words, a process whereby social actors involved in the program could become active participants and beneficiaries of the assessment. This type of evaluation, developed together with researchers at the University of Turin, led to the use of mixed techniques, such as questionnaires for students, participant and non-participant observation of classroom work, and in-depth interviews with teachers and with scientists. The aims were manifold, and included identifying the motivations of different actors (students, teachers, scientists) for participating in an extra-curricular initiative, gathering opinions about the project, and estimating the overall degree of satisfaction at the end of the project.

In the following paragraphs, I will focus only on a few considerations regarding student participation of the Scienza Attiva session (academic year 2013-2014) - for considerations regarding other aspects or actors of project, see Cornali (2015) and Agnella et al. (2015).

In the 2013-2014 school year, a large number of students and teachers from upper secondary schools throughout Italy participated together with scientists in the Scienza Attiva project, dealing with the following socio-scientific issues: stem cells, nanotechnology and energy. The project - which lasted six months and included three live events with students, teachers and scientists from all over Italy - involved 4,224 students, 200 teachers and 49 scientists. Platform activity 
logs testify to the lively interactions between students and students and between students and scientists during the Scienza Attiva initiative. In fact, during that edition, 1,060 posts, 273 scientific documents, 180 questions addressed to scientists, 144 answers sent to students and 111 student proposals and recommendations to scientists and policy makers have been published on the web platform.

The study sought in particular to obtain information in two different domains: 1) students' opinions about the Scienza Attiva project, both with regard to several substantive aspects - such as the objectives pursued and the method used and as regards certain more practical aspects, such as the website's usability, how the different stages were organized and scheduled, and so forth; 2) students'opinions about the world of science and scientists, and the relationship between science and society.

For this reason, all students were asked at the end of the Scienza Attiva session to answer an anonymous semi-structured questionnaire - containing both open-ended and closed ended questions - administrated electronically.

As was expected from the fact that filling in the questionnaire was entirely voluntary, the response rate was quite low, with a total of 449 completed questionnaires. Although the researchers considered making the questionnaire mandatory, the Scienza Attiva team thought this was not appropriate because it would create an additional burden for the students, thus resulting in resentment. Since the sample was self-selected, the only substantive conclusions that can be made are obviously purely exploratory. So, although the results may not be generalizable nevertheless, they offer some interesting insights. In general, it can be said that the responses provided by the students - consisting of a majority of females (52.1\%), mean age 17.4 years, resident in Northern Italy (62.3\% versus $20.6 \%$ residing in Central Italy and $17.1 \%$ living in the South and Islands) and attending a science or technology-oriented high school $(63.7 \%)$ - point to a certain ambivalence and indecision regarding a number of sensitive issues, as well as some unexpected results.

This was clear in the first area investigated, opinions about the Scienza Attiva project, where students' answers were surprising and sometimes contradictory. The majority of respondents (59.9\%) said they agreed strongly or somewhat with the statement "With Scienza Attiva I had fun when dealing with scientific problems" (4 or 5 on a 5-point scale) and appreciated $(65.7 \%)$ the web platform made available to them, judging it to be "easy and effective". More important, $68.8 \%$ of students agreed or agreed strongly with the statement: "Participating in the Scienza Attiva project increased my capacity for reflection on scientific problems". These appreciations of the project seem to recognize the usefulness of discussing socio-scientific issues in the formal education setting. It is thus surprising that, at the same time, the majority of students agree with the statement "In order to achieve a good level of scientific competence and a critical knowledge, well-designed curricula, good teachers and intensive individual study are more useful than projects of this kind" ( $51 \%$ of the students agree very much or somewhat, as against $42.6 \%$ who disagree strongly or to some extent). Unexpectedly, furthermore, students showed greater interest in analyzing the documents provided by the scientists (a stage that $52.5 \%$ of respondents rated as very interesting or extremely interesting) than in on-line dialog with them (rated as very interesting or extremely interesting by $41.8 \%$ of respondents). These results could suggest that young people prefer well-established traditional methods ("Information" stage) to innovative and unusual proposals ("Dialog" stage). However, this interpretation of students as predominately conservative in attitude and disinclined for greater direct involvement is belied by their preference for the "Final proposals" stage, by far their favorite (rated as very interesting or extremely interesting by $63.2 \%$ of respondents).

The highly contrasting opinions that were collected show that STS programs such as Scienza Attiva are difficult to integrate in a school environment where traditional teaching methods prevail. This would also appear to be confirmed by the comments volunteered by several students:

Scienza Attiva is an interesting experience, but if you can't fit it in with your ordinary school commitments, it's just a burden and not a useful source of learning (St. 440).

Scienza Attiva in my opinion is a pretty useless project because it doesn't give you much knowledge unless you do individual research, and you don't need this whole portal to do that. It also robs precious hours from your lesson time, and does not make school life any easier. In fact it makes it worse [...], because students are questioned on topics that they've barely covered, since they don't know what to study (St. 238).

A waste of time, might as well read a scientific journal (St. 147).

From these comments emerges a stronger need and demand for training and education than participation and. This need probably is emphasized by the school setting in which the project takes place, but this does not reduce the interest in discussing thorny techno-scientific problems or involvement in participative decision-making. Thus students seem to oscillate between the appeal of the familiar ways of conveying knowledge and the need to be active participants.

Although it was not easy to devote your time entirely to Scienza Attiva because of other school activities, the project has provided us with knowledge and information that we will be glad to have in the future, and has increased our 
ability to work in groups and to listen (St. 108).

It was certainly important to have a way to exchange ideas with other kids and schools throughout Italy and certainly to have closer contact with experts and scientists (St. 43).

I liked the fact that the project had students participate directly, so that they had an opportunity to hold debates and discussions with each other to reach a consensus. I also appreciate the role that the teacher had during the entire project, i.e., as a supervisor and mediator, not a "professor" (St. 106).

Direct interaction with experts is challenging and interesting (St. 369).

Lastly, a few words are about the second area of interest, namely the students' opinions about the world of science and scientists, and the relationship between science and society. In this area as in the previous, conflicting views emerged. Although the phase of dialog with scientists was not the one preferred by students, it seems to have been positive since more than half of the students (52.8\%) said that participating in Scienza Attiva increased their awareness that "Dialog with scientists is possible". Despite this appreciation, a certain distrust of scientists was found: less than half of the students (41\%) believe that "Scientists are neutral and objective", while only $14 \%$ think that "Scientists inform the public enough". Several studies (see, for example, Hansen et al., 2003) have shown that, especially in cases of scientific controversies, it is not the generalized trust in science that is be questioned, but rather the trustworthiness of some of the scientific community's members. This finding is confirmed by the students participating in Scienza Attiva, who express reservations about scientists but agree in having considerable confidence in science, its fairness and the benefits of its applications. Thus, $85.2 \%$ agree with the statement "Advances in science and technology usually produce benefits to society", and $74.3 \%$ with the statement "Science and technology are always neutral: it is the use to which they are put that makes them good or bad". But this is only a partial confirmation, because students' opinions about science are divided - as were their opinions about scientists. In particular, respondents are strikingly divided regarding the statement "Contemporary science threatens fundamental values (e.g., the sacredness of human life and nature)": $32.9 \%$ of students agree, $26.1 \%$ are uncertain and 34.5\% disagree. The Scienza Attiva project aims at overcoming the opposing narratives of "blind fear" or "unconditional hope" in science, inviting students to enter into the merits of scientific and technological issues and look at them from several angles. It seems clear, however, that when it comes to "non-negotiable values", reconciling divergent opinions is particularly arduous. For this reason, efforts to introduce in schools the discussion and analysis of controversial socio-scientific issues which set different values, beliefs and opinions against each other would appear to be particularly useful (see, in this regard, Albe, 2008). These experiences can undoubtedly be considered an important part of the so-called 'science education for citizenship', or, as Kolstø (2008) put it, the kind of scientific education that aims 'at preparing students for active, informed, critical and responsible participation in situations where insights into different aspects of science might improve the quality of students' participation' (p. 978).

\section{Discussion}

The interest sparked by the Scienza Attiva project is demonstrated by the growing number of schools that participate in the initiative each year, as well as by international prizes it has received (i.g. EngageU Award in the European Competition for Best Innovations in University Outreach and Public Engagements). Obviously, there are also a number of problems. For an analytical examination of the critical aspects, it can be useful establish how many of them depend on the usual procedures followed in deliberative processes, and how many in fact depend on the project's specific characteristics.

The first category, namely the critical aspects of the "consensus conference" model, includes the shortcomings I labeled above as "inadequate knowledge", "selective representation", "techno-scientific dominance" and "substantial inconclusiveness".

The problem of "inadequate knowledge" does not appear to affect the project, except to the extent that any cognitive process is necessarily imperfect and incomplete, and this is all the truer of controversial issues. In fact Scienza Attiva devotes particular attention to the training/education stage: the documents (text files and videos) available to students offer complete and detailed information. Moreover - and this is something that makes the project, if not perhaps unique, at least very rare - students have a chance to discuss issues with scientists who are among Italy's leading experts.

The problem of "selective representation" is, by contrast, quite relevant. Scienza Attiva is aimed at a specific category of young people, i.e., students, whom it can be assumed are particularly interested in analyzing and solving problems. Since the topics covered by the project concern techno-science, the participating schools are mainly science-oriented and technical high schools ("liceo scientifico" or "istituto tecnico"), whose students have a positive attitude towards science: though they may not regard themselves as entirely competent in the subject, they are at least attracted. Not only, but since Scienza Attiva is an extra-curricular elective project, it is likely that the schools that participate are among the 
best, where the most motivated teachers work and which can offer their students - attentive, highly engaged young people - an additional activity. Together, these features paint a picture of the Scienza Attiva participants as members of "scholastic elite".

"Techno-scientific dominance", which many authors see as affecting "consensus conferences", also seems to emerge in Scienza Attiva. As just mentioned, the participating students attend science-oriented schools, and the educators who accompany them in this project are mainly teachers of mathematics, physics or biology. Even the experts who contribute to the discussion are mostly from the hard sciences (the most recent panel included only a couple of specialists in public communication and one ethicist). As the stated aims of Scienza Attiva are to make participants more aware of the controversial aspects and the social impact of a techno-scientific issue, and develop their capacity for critical thinking, it would probably be better to involve a larger number of social scientists and stakeholders (e.g., representatives of citizen's, groups, the business community, etc.).

The fourth problem, "substantial inconclusiveness", does not seem to be relevant to an assessment of the Scienza Attiva project. However motivated, informed and interested the students may be, the project neither claims nor expects that they can make a substantial contribution to widely debated technical and scientific controversies. Though the students' proposals are sent to the scientists with whom they have interacted and to representatives of several national and local institutions (including the Ministry of Education and the provincial administration), their value lies entirely in providing testimony. However, we should ask ourselves whether the students' perception that the whole process will be little more than a kind of simulation increases or detracts from their confidence in the practices of deliberative democracy.

Moving on from the problems typical of "consensus conferences" to the critical aspects of the project itself, the main problem that emerges is the high drop-out rate. In fact, only about half of the classes who enroll actually conclude the project. There can be many reasons for this: the project may turn out to be more difficult and challenging than teachers had expected, or difficulties may arise in the classroom (falling behind in the curriculum, loss of motivation) that impede its continuation. Other problems can result from misunderstanding, misrepresenting (or distorting) the project's goals: teachers (because of their role and their background) may put more emphasis on the didactic aspects than on active participation, discussion and deliberation. In some cases, this kind of misapprehension has even led teachers to grade the work done by students during Scienza Attiva. One of the factors that may contribute to a failure to understand the project's actual purpose is that this initiative is often the only one of its kind in an otherwise highly traditional educational setting where students are not particularly encouraged to take part in discussions of controversial issues, much less to be involved in formulating concrete proposals.

So can it be said that participating in the Scienza Attiva project in some way contributed to building better CSL among young people? As mentioned earlier, the project evaluation program was purely exploratory, so it does not allow us to draw substantive and generalizable conclusions. The data collected, however, were useful in identifying trends and hitherto unknown aspects which deserve further scrutiny. The picture that emerges is one of bright spots and shadows. While showing appreciation for the initiative - expressing, for example, positive opinions on the quality of classroom interaction and satisfaction with the answers given by the scientists - only $38.5 \%$ of students said that participating in Scienza Attiva made them more aware of the fact that "Having a good level of scientific knowledge improves the ability to exercise informed citizenship".

The effects of introducing practices of deliberative democracy in schooling are hard to gauge. Does participating as a student in a consensus conference, a citizens' jury, or a scenario workshop predict future involvement in discursive and informed interaction between citizens or other forms of civic activism? It is difficult to say: this is a question that must be judged in the long term. But according to the students' statements, the answer might be yes. Indeed, 59.4\% of the students answered in the affirmative when asked "Would you be interested in participating in the project again, with other scientific issues?" (18.9\% were uncertain and 12\% said no), demonstrating their regard for these practices.

Of course, this is not sufficient to conclude that in the near future they will engage in practices of deliberative democracy and exert active, informed citizenship. It thus seems preferable to look at the more immediate benefits of participatory exercises at school. The first such benefits that can be observed are cognitive. To use the categories proposed by Powell and Kleinman (2008) about the virtues of the consensus conference model, it can be said that Scienza Attiva gave students an opportunity to acquire new knowledge about: 1) science and technology; 2) social, cultural, institutional and economic aspects of science knowledge; 3) principles, functions, purposes and practices of democratic deliberation (in this case, the "consensus conference" model). Gains in knowledge were not the only benefits: arguably participating in Scienza Attiva stimulated and activated social skills such as the ability to listen, cooperative work and capacities needed to engage in debate about scientific and technological matters.

\section{Conclusion}

The most evident manifestation of the shift in science communication from the "deficit model" to the "dialog model" is 
the proliferation of initiatives centering on participation and public deliberation about technological and scientific issues. Although these processes have been welcomed for the positive values they convey (dialog, constructive discussion, mediation), doubt has been cast on their representativeness, articulation, impacts and outcomes. Reactions have thus been mixed: growing expectations on the one hand, some rather substantial doubts on the other. Questions about the usefulness and advisability of engagement practices are all the more likely to arise when these practices are offered in a school setting. What are the specific contributions provided to the achievement of educational purposes? Are goals of deliberative practices actually achievable at school and with students?

This is relevant question. And science is now so pervasive, and technological innovations come at such a breakneck pace, that the task of science education is more complex than ever before. The challenge now is to make most people capable of seeing and understanding the impact of science and technology in everyday life, of thinking critically about them, participating in discussions and making informed decisions. A full forty years ago, Gallagher noted that "For future citizens in a democratic society, understanding the interrelationships of science, technology and society may be as important as understanding the concepts and processes of science" (Gallagher, 1971, p. 337). Consequently, an important challenge for science education is to find the most effective ways to support students' critical examination of scientific arguments. Introducing practices inspired by public deliberation in the formal education setting could be an answer to this need, as they provide students with grounding in scientific issues while encouraging active participation in debate about controversial topics. Building widespread CSL is a complex process, and the Scienza Attiva experience shows that the benefits of participatory practices in school can be appreciated only in a rather broad timespan. But if the hoped-for results are to be achieved, these initiatives should be expanded in other levels and sectors of education, rather than being reduced to the level of extra or occasional events that depend on the personal involvement and dedication of individual teachers or the efforts of a few centers of scientific culture, as was the case of Scienza Attiva. Lastly, far more should be done to involve students from minority groups, who are generally less active in exercising their citizenship.

\section{Acknowledgements}

I would like to thank the components of Scienza Attiva's team who generously shared their time and insights.

\section{References}

Agnella, S., Cornali, F., Latini, G., \& Pomatto, G. (2015). I giovani e la scienza partecipata. Metodo e valutazioni. In A. Parola \& L. Denicolai (Eds) Tecnologie e linguaggi dell'apprendimento: traiettorie e sfide media educative. Ariccia (RM): Aracne.

Aikenhead, G. S. (2002). Renegotiating the culture of school science: Scientific literacy for an informed public. Paper presented to Lisbon's School of Science Conference, Universidade de Lisboa, Portugal, May 17.

Aikenhead, G. S. (2003). STS education. A rose by any other name. In R. Cross (Ed) A vision for science education: Responding to the work of Peter Fensham. London-New York: Routledge Falmer.

Albe, V. (2008). Students' positions and considerations of scientific evidence about a controversial socio-scientific issue. Science and Education, 17(8-9), 805-827. https://doi.org/10.1007/s11191-007-9086-6

American Association for the Advancement of Science (1989). Science for all Americans. Washington DC: AAAS.

American Association for the Advancement of Science (2001). Atlas of science literacy. Washington DC: AAAS.

Andersen, I. E., \& Jæger, B. (1999). Scenario workshops and consensus conferences: Towards more-making. Science and Public Policy, 26(5), 331-340. https://doi.org/10.3152/147154399781782301

Arnos, A. B. (1983). Achieving wider scientific literacy. Daedalus 112(2), 91-122.

Bauer, M. W., Allum, N., \& Miller, S. (2007). What can we learn from 25 years of PUS survey research? Liberating and expanding the agenda. Public Understanding of Science, 16(1), 79-95. https://doi.org/10.1177/0963662506071287

Bennett, J., Lubben, F., \& Hogarth, S. (2007). Bringing science to life: A synthesis of the research evidence on the effects of context-based and STS approaches to science teaching. Science Education, 91(3), 347-370. https://doi.org/10.1002/sce.20186

Bingle, W. H., \& Gaskell, P. J. (1994). Scientific literacy for decision making and the social construction of scientific knowledge. Science Education, 78(2), 185-201. https://doi.org/10.1002/sce.3730780206

Bowker, G. C., \& Star, S. L. (1999). Sorting things out: Classification and its consequences. Cambridge: MIT Press.

Burgess, M. M. (2014). From 'trust us' to participatory governance: Deliberative publics and science policy. Public Understanding of Science, 23(1), 48-52. https://doi.org/10.1177/0963662512472160

Cornali, F. (2015). Scienziati a scuola. La comunicazione della scienza nei contesti dell'istruzione formale. In S. 
Scamuzzi \& G. Tipaldo (Eds) Apriti scienza. Il presente e il futuro della comunicazione della scienza in Italia tra vincoli e nuove sfide. Bologna: il Mulino.

Cutcliffe, S. H. (1996). National association for science, technology and society. In R.E. Yager (Ed) Scienceltechnology/society as reform in science education. Albany: SUNY Press.

Davis, K. S. (2003). "Change is hard": What science teachers are telling us about reform and teacher learning of innovative practices. Science Education, 87(1), 3-30. https://doi.org/10.1002/sce.10037

Driver, R., Newton, P., \& Osborne, J. (2000). Establishing the norms of scientific argumentation in classrooms. Science Education, 84(3), 287-312. https://doi.org/10.1002/(SICI)1098-237X(200005)84:3<287::AID-SCE1>3.0.CO;2-A

Dryzek, J. S. (2000). Deliberative democracy and beyond. Liberals, critics, contestations. New York: OUP.

Dunkerley, D., \& Glasner, P. (1998). Empowering the public? Citizens' juries and the new genetic technologies. Critical Public Health, 8(3), 181-192. https://doi.org/10.1080/09581599808402906

European Commission (2002). Science and society action plan. Luxembourg: Office for Official Publications of the European Communities.

European Parliament and Council of the European Union (2006). Recommendation on key competences for lifelong learning, December, 18 (2006/962/EC).

Fishkin, J. (2009). When the people speak: Deliberative democracy and public consultation. Oxford: University Press.

Gallagher, J. J. (1971). A broader base for science education. Science Education, 55(3), 329-338. https://doi.org/10.1002/sce.3730550312

Gaskell, J. P. (2001). STS in a time of economic change: What's love got to do with it? Canadian Journal of Science, Mathematics and Technology Education, 1, 385-398. https://doi.org/10.1080/14926150109556481

Gilbert, J. K. (2006). On the nature of 'context' in chemical education. International Journal of Science Education, 28(9), 957-976. https://doi.org/10.1080/09500690600702470

Goven, J. (2003). Deploying the consensus conference in New Zealand: Democracy and de-problematization. Public Understanding of Science, 12(4), 423-440. https://doi.org/10.1177/0963662503124006

Habermas, J. (1997). The theory of communicative action. Vol. 1- Reason and the Rationalization of Society. Cambridge: Polity.

Hansen, J., Holm, L., Frewer, L., Robinson, P., \& Sandøe, P. (2003). Beyond the knowledge deficit: Recent research into lay and expert attitudes to food risks. Appetite, 41(2), 111-121. https://doi.org/10.1016/S0195-6663(03)00079-5

Hilgartner, S. (1990). The dominant view of popularization: Conceptual problems, political uses. Social Studies of Science, 20(3), 519-539. https://doi.org/10.1177/030631290020003006

Horlick-Jones, T., Walls, J., Rowe, G., Pidgeon, N., Poortinga, W., \& Murdock, G. (2007). The GM debate: Risk, politics and public engagement. London: Routledge.

Irwin, A. (2001). Constructing the scientific citizen: Science and democracy in the biosciences. Public Understanding of Science, 10(1), 1-18. https://doi.org/10.1088/0963-6625/10/1/301

Jasonoff, S. (2004). Science and citizenship: A new synergy. Science and Public Policy, 31(2), 90-94. https://doi.org/10.3152/147154304781780064

Kolst $\varnothing$, S. D. (2000), Consensus projects: Teaching science for citizenship. International Journal of Science Education, 22(6), 645-664. https://doi.org/10.1080/095006900289714

Kolstø, S. D. (2001). To trust or not to trust, ...pupils' ways of judging information encountered in a socio-scientific issues. International Journal of Science Education, 23(9), 877-901. https://doi.org/10.1080/09500690010016102

Kolst $\varnothing$, S. D. (2008). Science education for democratic citizenship through the use of the history of science. Science and Education, 17(8), 977-997. https://doi.org/10.1007/s11191-007-9084-8

Lubben, F., Bennett, J., Hogarth, S., \& Robinson, A. (2005.) The effects of context-based and Science-Technology-Society (STS) approaches in the teaching of secondary science on boys and girls, and on lower-ability pupils. IEPPI-Centre Social Science Research Unit Research Evidence in Education Library. London: University of London.

MacKenzie, D. (1996). Knowing machines. Essays on technical change. Cambridge: MIT Press. 
Miller, J. D. (1983). Scientific literacy: A conceptual an empirical review. Daedalus, 112(2), $29-48$.

Miller, J. D. (2010.) Adult science learning in the internet era. Curator, 53(2), 191-208. https://doi.org/10.1111/j.2151-6952.2010.00019.x

Miller, J. D., \& Pardo, R. (2005). Civic scientific literacy and attitude to science and technology: A comparative analysis of the European Union, the United States, Japan and Canada. In M. Diekers \& C. von Grote (Eds) Between understanding and trust: the public, science and technology. London-New York: Routdlege.

National Curriculum Council (1989). Science: Non-statutory guidance. London: National Curriculum Council.

National Research Council (1996). National Science Education Standards. Washington, DC: National Academy Press.

National Science Foundation (1983). Educating Americans for the twenty-first century: Report of the National Science Board Commission on pre-college education in mathematics, science and technology. Washington, DC: National Science Foundation.

OECD (2013). Pisa 2015 draft science framework. Paris: Oecd Publishing.

Powell, M., \& Kleinman, D. L. (2008). Building citizen capacities for participation in nanotechnology decision-making: The democratic virtues of the consensus conference model. Public Understanding of Science, 17(3), 329-348. https://doi.org/10.1177/0963662506068000

Rawls, J. (1993). Political liberalism. New York: Columbia University Press.

Royal Society (1985). The public understanding of science. London: The Royal Society.

Ryder, J. (2002). School science education for citizenship: Strategies for teaching about the epistemology of science. Journal of Curriculum Studies, 34(6), 637-658. https://doi.org/10.1080/00220270210148434

Sadler, T. D. (2010). Book review: Controversy in the classroom: the democratic power of discussion by Diana E. Hess. Science Education, 94(4), 760-762. https://doi.org/10.1002/sce.20380

Sadler, T. D., Chambers, F. W., \& Zeidler, D. L. (2004). Student conceptualisations of the nature of science in response to a socioscientific issue. International Journal of Science Education, 26(4), 387-410. https://doi.org/10.1080/0950069032000119456

Science Council of Canada (1984). Science for every citizen: Educating Canadians for tomorrow's world. Summary of Report No. 36. Ottawa: Supply and Service Canada.

Shamos, M. (1995). The myth of scientific literacy. New Brunswick, NJ: Rutgers University Press.

Shen, B. S. (1975). Science literacy and the public understanding of science. In S.B. Day (Ed) Communication of scientific information. New York: Karger. https://doi.org/10.1159/000398072

Tlili, A., \& Dawson, E. (2010). Mediating science and society in the EU and UK: From information-transmission to deliberative democracy? Minerva, 48(4), 429-461. https://doi.org/10.1007/s11024-010-9160-0

Turner, S. (2008). School science and its controversies; or, whatever happened to scientific literacy? Public Understanding of Science, 17(1), 17-55. https://doi.org/10.1177/0963662507075649

UNESCO (1983). Science for all. Bangkok: Unesco Office for Education in Asia and the Pacific.

Wilsdon, J., \& Willis, R. (2004). See-through science. Why public engagement needs to move upstream. London: Demos.

Wynne, B. (1996). May the sheep safely graze? A reflexive view of the expert-lay knowledge divide. In S. Lash, B. Szerszynski \& B. Wynne (Eds) Risk, environment and modernity: towards a new ecology. London: Sage Publications.

Wynne, B. (2006). Public engagement as a means of restoring public trust in science: Hitting the notes, but missing the music? Community Genetics, 9(3), 211-220. https://doi.org/10.1159/000092659

\section{Copyrights}

Copyright for this article is retained by the author(s), with first publication rights granted to the journal.

This is an open-access article distributed under the terms and conditions of the Creative Commons Attribution license which permits unrestricted use, distribution, and reproduction in any medium, provided the original work is properly cited. 